\title{
Review: silicone breast implants do not increase the risk for connective tissue diseases
}

Janowsky EC, Kupper LL, Hulka BS. Meta-analyses of the relation between silicone breast implants and the risk of connective-tissue diseases. $N$ Engl J Med 2000 Mar 16;342:781-90.

Source of funding: Administrative Office of the US Courts.

QUESTION: Are silicone breast implants associated with an increased risk for connective tissue diseases (rheumatoid arthritis, systemic lupus erythematosus, scleroderma or systemic sclerosis, the Sjögren syndrome, dermatomyositis or polymyositis, all definite connective tissue diseases, or other autoimmune or rheumatic conditions)?

\section{Data sources}

Studies were identified by searching Medline, TOXLINE, Current Contents Online, and Dissertations Abstracts Online with terms related to breast implants and connective tissue diseases.

\section{Study selection}

Studies were selected if internal comparison groups were evaluated and sufficient data were available for analysis of women (not disease events) using $2 \times 2$ tables for categories of disease and implants.

\section{Data extraction}

Data were extracted on year and country of publication; funding; study design; population characteristics and numbers; type, date, and reason for implant; disease characteristics; time from implantation to symptoms; and confounding factors.

\section{Main results}

9 cohort studies, 9 case control studies, and 2 cross sectional studies met the inclusion criteria. Medical records provided data on the status of definite connective tissue disease in 19 studies; 1 study relied on self reports. Information on other autoimmune and rheumatic conditions came from medical reports in 16 studies and from self reports in 4 studies. The information in the table shows that silicone breast implants are not associated with increases in connective tissue diseases. 1 large cross sectional study was excluded because of methodological problems, including unverified self reports of disease status. Inclusion of this study in the analyses slightly increases all risks, and the risk for all connective diseases becomes significant (relative risk 1.14, 95\% CI 1.01 to 1.28). Subgroup analysis of the 6 studies of silicone gel implants also shows no increased risk for any disease category.

\section{Conclusion}

Silicone breast implants, including silicone gel implants, are not associated with an increased risk for all connec- tive tissue diseases combined or for individual diseases or conditions after adjustment for confounding factors and study outliers.
Silicone breast implants and the risk for connective tissue diseases (1 study was excluded for methodological problems)

\begin{tabular}{lll} 
Diseases & $\begin{array}{l}\text { Number of } \\
\text { studies }\end{array}$ & $\begin{array}{l}\text { Adjusted relative risk } \\
(95 \% \mathrm{Cl})\end{array}$ \\
All connective tissue diseases & 13 & $0.80(0.62 \text { to } 1.04)^{\star}$ \\
\hline Rheumatoid arthritis & 7 & $1.04(0.72 \text { to } 1.51)^{\star}$ \\
\hline Systemic lupus erythematosus & 4 & $0.65(0.35 \text { to } 1.23)^{\star}$ \\
\hline Scleroderma or systemic sclerosis & 4 & $1.01(0.59 \text { to } 1.73)^{\star}$ \\
\hline Sjögren syndrome & 3 & $1.42(0.65 \text { to } 3.11)^{\star}$ \\
\hline Dermatomyositis or polymyositis & 1 & $1.52(0.97 \text { to } 2.37)^{\star}$ \\
\hline Other autoimmune or rheumatic conditions & 6 & $0.96(0.74 \text { to } 1.25)^{\star}$ \\
\hline
\end{tabular}

Not significant.

\section{COMMENTARY}

The controversy about a possible link between breast implants and the development of connective tissue diseases still smolders. Janowsky et als meta-analysis includes 8 studies published since the previous meta-analysis in 1996. The method of identifying relevant studies and the inclusion criteria for the analysis were rigorous. The review discusses methodological issues associated with 1 very large study that is based on self reported and unverified disease. ${ }^{1}$ The results of this study disagree with and show a stronger association than most of the results of the smaller studies, and because of its size, the large study swamps the results of the others. To help to resolve these issues, Janowsky $e t$ al present 2 sets of analyses: one that includes and one that excludes the large study. They conclude, mainly on the basis of the smaller, stronger studies (a choice with which I concur), that there is no evidence of increased risks for classical connective tissue diseases with silicone breast implants.

All breast implants are enclosed in silicone, and some contain silicone gel. Subanalysis of 6 studies (excluding the study by Hennekens $e t a l^{1}$ ) that present data on silicone gel filled implants shows no association with all connective tissue disorders combined (summary adjusted relative risk 0.82 , CI 0.46 to 1.46). Although the question about whether silicone breast implants are associated with connective tissue diseases may have been settled "beyond reasonable doubt," 1 issue remains unsettled: do women who have had cosmetic breast surgery with or without implants experience a higher frequency of non-specific rheumatic and neurological symptoms? $?^{23}$ If they do, then these may either be premorbid events in women who elect to have breast surgery or a consequence of the surgery.

Deborah P M Symmons, MD University of Manchester Medical School Manchester, UK

1 Hennekens CH, Lee IM, Cook NR, et al.JAMA 1998;279:198.

2 Friis S, Mellemkjaer L, McLaughlin JK, et al. Ann Plast Surg 1997;39:1-8.

Winther JF, Bach FW, Friis S, et al. Neurology. 1998;50:951-5. 